\title{
Perceptions and Factors Affecting Patient Safety Culture of Employees in Pediatric Services
}

\author{
(D) Yüksel Karademirler1, (D) Gülay Manav2 \\ 1 Uludağ University Faculty of Medicine, Department of Pediatrics, Bursa, Turkey \\ 2 Muğla Sıtkı Koçman University Faculty of Health Science, Deparment of Pediatric Nursing, Muğla, Turkey
}

\begin{abstract}
Aim: In this study, some factors affecting the patient safety culture and perceptions of health care workers working in pediatric clinics were examined.

Materials and Methods: This descriptive type of research was conducted with a total of 461 health care workers.

Results: $36.2 \%$ of these healthcare workers were aged $26-35$ and $54.8 \%$ were working as nurses. The hospital health workers patient safety culture survey showed that they reached an overall score of $51 \%$ in the hospital survey. Employees received the highest positive response from "in-unit teamwork" sub-dimension with $71.55 \%$ and the lowest positive response from "non-punitive response to error" sub-dimension with $28.06 \%$. It was determined that the majority of healthcare workers working in pediatric services knew the concept of patient safety and implemented patient safety initiatives while providing care.
\end{abstract}

Conclusion: As a result, it is recommended that the patient safety culture levels of the employees should be continuously evaluated between the institution and the employees.

Keywords: Patient safety, pediatric health team, safety culture

\section{Introduction}

Quality-oriented arrangements, performance-based payments and open reporting have contributed to focusing on quality and safety criteria in health care (1). Improving safety culture in health care is a fundamental component of preventing errors and improving overall health care quality (2). In patient safety culture, the important thing for the members of the organization is how to do the work carried out, communication between departments, and the values of how structures and systems are demonstrated in the norms of behaviour that support patient safety (3). The culture of an organization is reflected in its motivation to learn from reporting, analysis and medical errors (4). The evaluation of safety culture in hospitals is the first step in identifying their safety culture (5).

Patient safety has become a high priority in health care systems in the world over the past two decades and is an important issue in pediatric healthcare services $(6,7)$. In the United States, after cancer and heart disease, medical errors are reported to be the third most important cause of death. 5.7 million children under 19 years of age have been examined and children (including those under one year, especially newborns younger than one month) are shown to be the most vulnerable group affected by patient safety incidents (8). The majority of preventable patient safety incidents not only affect the child and their family but also 
increase the length of hospital stay and hospital costs $(9,10)$.

The effectiveness of patient safety in children increases with the knowledge of physical and developmental features specific to developmental periods. Developmental periods bring with them active and risky behaviours in pediatrics. In addition, due to the lack of predictable developmental characteristics of children, the risk of failure of health workers increases (11).

Research on patient safety culture in pediatric clinics in our country has not been available. The formation of patient safety culture requires data on this subject be collected first. In this context, this research is a preliminary study to determine the understanding of health care workers' safety culture working practices in pediatric clinics.

\section{Research questions:}

1. What are the levels of safety culture in general and in sub-groups of health workers working in pediatrics services?

2. Is there any difference in the perception of safety culture in terms of the individual characteristics of health workers working in pediatric services?

3. Is there any difference in the perception of the safety culture in terms of the working characteristics of health workers working in pediatric services?

\section{Materials and Methods}

\section{Study Design}

This descriptive study was conducted to examine the perceptions and factors affecting patient safety culture of healthcare workers working in the pediatric clinics of two children's hospitals.

\section{Statistical Analysis}

Data were collected from 253 nurses, 50 physicians and 158 other health workers $(n=461)$. A survey method was used as the data collection tool in this research. The "Hospital Survey on Patient Safety Culture (HSoPSC)" and "Personal Information Form" were included in the survey form in order to measure the perceptions of health workers working in pediatrics services concerning patient safety culture. Statistical analysis was performed using a statistical package program.

\section{Ethical Considerations}

The approval of Uludağ University Faculty of Medicine Clinical Research Ethics Committee (52588837-000/421) concerning the subject, purpose and method of the research were obtained, and the study was launched upon obtaining permission for clinical practice from the hospitals included in the research. Individual permission from the participants was acquired via an informed consent form during the study.

\section{Results}

Of all the health workers participating in the survey, $64.9 \%$ were married, $36.2 \%$ were in the age range of $26-35$ years, $54.8 \%$ were nurses, $34.27 \%$ were doctors, with the rest being healthcare workers. According to the study characteristics, $61.4 \%$ of the participants worked $40-49$ hours a week, and $65.5 \%$ of the pediatric service workers had been working in these services for 1-5 years, while $33.2 \%$ had a work experience of 16 years or more. $88.5 \%$ of volunteers participating in this research were able to communicate directly with children and their families. $45.6 \%$ of the participants were in the pediatric service, $24.3 \%$ in pediatric intensive care, $8.5 \%$ were working in pediatric surgical services, while $21.7 \%$ were employed in other units (adult and child mixed services, pharmacy, laboratory, radiology, etc).

The 'patient safety of pediatric service personnel hospital survey' positive response averages are given in Table I.

As far as the health workers' patient safety culture is concerned, the hospital survey's overall score of $51.00 \%$ was recorded. The lowest positive response was for the "non-punitive response to error" with $28.06 \%$ of the total responses, while "teamwork within units" had the highest

Table I. The health workers hospital survey on patient safety culture positive response average

\begin{tabular}{|l|l|}
\hline $\begin{array}{l}\text { Hospital survey on patient safety culture sub- } \\
\text { dimensions }\end{array}$ & $\begin{array}{l}\text { Positive } \\
\text { answer } \\
\text { (\%) }\end{array}$ \\
\hline 1. Overall perceptions of patient safety & 62.35 \\
\hline 2. Frequency of events reported & 40.13 \\
\hline 3. Teamwork across units & 47.05 \\
\hline 4. Handoffs and transitions & 52.97 \\
\hline $\begin{array}{l}\text { 5. Supervisor/manager expectations and actions } \\
\text { promoting patient safety }\end{array}$ & 46.70 \\
\hline 6. Organizational learning - continuous Improvement & 51.50 \\
\hline 7. Teamwork within units & 71.55 \\
\hline 8. Communication openness & 49.76 \\
\hline 9. Feedback and communication about error & 42.30 \\
\hline 10. Non-punitive response to error & 28.06 \\
\hline 11. Staffing & 31.00 \\
\hline 12. Hospital management support for patient safety & 47.43 \\
\hline Overall score & 51.00 \\
\hline
\end{tabular}


positive response with $71.55 \%$. The results of Mann-Whitney $\mathrm{U}$ test showed significant differences between groups, and were utilized in order to determine whether the subscale positive response scores pointed to a significant difference in marital status (12). It was found that the scores of single health care workers were significantly higher in the subdimensions of "communication openness", "feedback and communication about error" and "handoffs and transitions". Those health workers who were married were shown to have higher average scores in the "staffing" sub-dimension.

The results of the Kruskal-Wallis test, which was conducted in order to determine whether the positive response scores differ significantly depending on the age of the patients in terms of "overall perceptions of patient safety", "teamwork across hospital units", "handoffs and transitions", "supervisor/manager expectations and actions promoting safety", "communication openness", and "hospital management support for patient safety" are presented in Table II. According to the results of this study, the difference between the groups was statistically significant.

Those healthcare workers aged 25 or less were found to have a significantly higher positive response average score than those between the ages of 26-35 in the "communication openness" and "organizational learningcontinuous improvement" sub-dimensions.

The scores of the sub-dimensions "handoffs and transitions" and "teamwork across hospital units" of the nurses participating in the study are higher than the scores of all other participants. This may be because nurses think the team is important when working with the child and family. As a result of the post-hoc test conducted to determine which sub-fields differ between the groups in terms of the weekly working hours, health workers who do not exceed 40 hours a week had a significantly higher positive answer score than those putting in an average of 50 working

\begin{tabular}{|c|c|c|c|c|c|}
\hline \multirow{3}{*}{$\begin{array}{l}\text { Hospital survey on patient safety culture sub- } \\
\text { dimensions } \\
\text { Individual features }\end{array}$} & \multirow{2}{*}{\begin{tabular}{|l} 
Marital status \\
Married \\
$(\mathrm{n}=299)$
\end{tabular}} & \multicolumn{2}{|l|}{ Age } & \multicolumn{2}{|l|}{ Job } \\
\hline & & $\begin{array}{l}26-35 \text { age } \\
(n=167)\end{array}$ & $\begin{array}{l}\text { Nurse } \\
(n=253)\end{array}$ & $\begin{array}{l}\text { Doctor } \\
(n=50)\end{array}$ & $\begin{array}{l}\text { Other* } \\
(n=158)\end{array}$ \\
\hline & \multicolumn{5}{|c|}{ Median (min:max) Mean \pm SD } \\
\hline 1. Overall perceptions of patient safety & $\begin{array}{l}75(0: 100) \\
64.29 \pm 32.03\end{array}$ & $\begin{array}{l}75(0: 100) \\
56.14 \pm 32.17\end{array}$ & $\begin{array}{l}75(0: 100) \\
67.19 \pm 31.58\end{array}$ & $\begin{array}{l}50(0: 100) \\
49.0 \pm 34.61\end{array}$ & $\begin{array}{l}75(0: 100) \\
65.68 \pm 29.22\end{array}$ \\
\hline 2. Frequency of events reported & $\begin{array}{l}33.3(0: 100) \\
41.13 \pm 44.01\end{array}$ & $\begin{array}{l}33.3(0: 100) \\
41.71 \pm 44.47\end{array}$ & $\begin{array}{l}33.3(0: 100) \\
42.94 \pm 44.14\end{array}$ & $\begin{array}{l}0(0: 100) \\
6.66 \pm 38.68\end{array}$ & $\begin{array}{l}33.3(0: 100) \\
46.63 \pm 43.54\end{array}$ \\
\hline 3. Teamwork across units & $\begin{array}{l}50(0: 100) \\
47.07 \pm 35.44\end{array}$ & $\begin{array}{l}25(0: 100) \\
40.56 \pm 32.19\end{array}$ & $\begin{array}{l}50(0: 100) \\
46.24 \pm 36.26\end{array}$ & $\begin{array}{l}25(0: 100) \\
38.0 \pm 33.97\end{array}$ & $\begin{array}{l}50(0: 100) \\
55.38 \pm 32.82\end{array}$ \\
\hline 4. Handoffs and transitions & $\begin{array}{l}50(0: 100) \\
52.75 \pm 34.49\end{array}$ & $\begin{array}{l}50(0: 100) \\
47.46 \pm 33.34\end{array}$ & $\begin{array}{l}75(0: 100) \\
58.2 \pm 32.11\end{array}$ & $\begin{array}{r}50(0: 100) \\
8.0 \pm 37.74\end{array}$ & $\begin{array}{l}50(0: 100) \\
52.69 \pm 36.19\end{array}$ \\
\hline $\begin{array}{l}\text { 5. Supervisor/manager expectations and actions } \\
\text { promoting patient safety }\end{array}$ & $\begin{array}{l}50(0: 100) \\
46.73 \pm 34.99\end{array}$ & $\begin{array}{l}25(0: 100) \\
42.66 \pm 34.52\end{array}$ & $\begin{array}{l}50(0: 100) \\
46.24 \pm 36.26\end{array}$ & $\begin{array}{l}50(0: 100) \\
37.5 \pm 32.83\end{array}$ & $\begin{array}{l}50(0: 100) \\
52.21 \pm 34.02\end{array}$ \\
\hline $\begin{array}{l}\text { 6. Organizational learning-continuous } \\
\text { improvement }\end{array}$ & $\begin{array}{l}66.7(0: 100) \\
56.18 \pm 35.11\end{array}$ & $\begin{array}{l}66.7(0: 100) \\
50.69 \pm 34.88\end{array}$ & $\begin{array}{l}66.7(0: 100) \\
58.5 \pm 35.44\end{array}$ & $\begin{array}{l}33.3(0: 100) \\
41.33 \pm 34.71\end{array}$ & $\begin{array}{l}66.7(0: 100) \\
56.75 \pm 34.59\end{array}$ \\
\hline 7. Teamwork within units & \begin{tabular}{|l}
$75(0: 100)$ \\
$71.41 \pm 34.05$ \\
\end{tabular} & $\begin{array}{l}75(0: 100) \\
67.66 \pm 35.6\end{array}$ & $\begin{array}{l}100(0: 100) \\
74.3 \pm 32.29\end{array}$ & $\begin{array}{l}75(0: 100) \\
71.05 \pm 33.12\end{array}$ & $\begin{array}{l}75(0: 100) \\
70.88 \pm 33.01\end{array}$ \\
\hline 8. Communication openness & $\begin{array}{l}33.3(0: 100) \\
47.26 \pm 33.6\end{array}$ & $\begin{array}{l}33.3(0: 100) \\
47.9 \pm 33.45\end{array}$ & $\begin{array}{l}66.7(0: 100) \\
53.75 \pm 32.81\end{array}$ & $\begin{array}{l}33.3(0: 100) \\
42.66 \pm 36.91\end{array}$ & $\begin{array}{l}66.7(0: 100) \\
51.27 \pm 34.62\end{array}$ \\
\hline 9. Feedback and communication about error & $\begin{array}{l}66.7(0: 100) \\
58.19 \pm 36.48\end{array}$ & $\begin{array}{l}66.7(0: 100) \\
57.68 \pm 37.03\end{array}$ & $\begin{array}{l}66.7(0: 100) \\
65.54 \pm 35.1\end{array}$ & $\begin{array}{l}66.7(0: 100) \\
52.66 \pm 39.32\end{array}$ & $\begin{array}{l}66.7(0: 100) \\
60.55 \pm 36.06\end{array}$ \\
\hline 10. Non-punitive response to error & $\begin{array}{l}33.3(0: 100) \\
29.65 \pm 32.74\end{array}$ & $\begin{array}{l}0(0: 100) \\
25.14 \pm 31.78\end{array}$ & $\begin{array}{l}33.3(0: 100) \\
31.21 \pm 32.33\end{array}$ & $\begin{array}{l}0(0: 100) \\
15.32 \pm 27.1\end{array}$ & $\begin{array}{l}33.3(0: 100) \\
30.59 \pm 34.07\end{array}$ \\
\hline 11. Staffing & $\begin{array}{l}25(0: 100) \\
34.03 \pm 21.62\end{array}$ & $\begin{array}{l}25(0: 75) \\
29.79 \pm 21.59\end{array}$ & $\begin{array}{l}25(0: 75) \\
29.74 \pm 19.6\end{array}$ & $\begin{array}{l}25(0: 75) \\
25.5 \pm 21.12\end{array}$ & $\begin{array}{l}25(0: 75) \\
37.34 \pm 21.44\end{array}$ \\
\hline $\begin{array}{l}\text { 12. Hospital management support for patient } \\
\text { safety }\end{array}$ & $\begin{array}{l}33.3(0: 100) \\
47.88 \pm 51.43\end{array}$ & $\begin{array}{l}33.3(0: 100) \\
42.71 \pm 38.01\end{array}$ & $\begin{array}{l}33.3(0: 100) \\
47.23 \pm 38.56\end{array}$ & $\begin{array}{l}33.3(0: 100) \\
32.66 \pm 37.18\end{array}$ & $\begin{array}{l}66.7(0: 100) \\
57.39 \pm 39.44\end{array}$ \\
\hline
\end{tabular}


hours a week in the sub-dimensions of "overall perceptions of patient safety", "supervisor/manager expectations and actions promoting patient safety", "communication openness", "non-punitive response to error", "feedback and communication about error", "staffing" and "hospital management support for patient safety" (Table III).

"Teamwork across units", "handoffs and transitions", "supervisor/manager expectations and actions promoting patient safety" and "staffing" also showed a statistically significant difference between groups determined on the basis of work experience of all the health workers. In particular, health workers with 16 years or less work experience registered higher scores in the sub-dimensions of "teamwork across units", "handoffs and transitions" and "staffing" (13).

Health workers working in other units responded more positively to "organizational learning-continuous improvement" than those working in the pediatric service and pediatric intensive care units, and the difference between these groups proved to be statistically significant. The positive scores received by healthcare professionals working in non-pediatric departments from the "hospital management support for patient safety" sub-dimension are significantly higher than those received by pediatric workers.

The study participants expressed their views on the presence or absence of patient safety in the hospital/ institution where they work (Table IV). According to this, the median positive percentages of the sub-dimensions of "overall perceptions of patient safety", "teamwork across units", "handoffs and transitions", "organizational learningcontinuous improvement", "teamwork within units", "communication openness", "feedback and communication about error", "non-punitive response to error", "staffing"

Table III. The comparison of hospital survey on patient safety culture subscale scores compared to weekly working hours

\begin{tabular}{|c|c|c|c|c|}
\hline \multirow{2}{*}{$\begin{array}{l}\text { Hospital survey on patient safety } \\
\text { culture sub-dimensions }\end{array}$} & \multicolumn{4}{|c|}{ Weekly working hours } \\
\hline & $\begin{array}{l}\text { It has not } \\
\text { exceeded } 40 \\
\text { hours }(n=84)\end{array}$ & $\begin{array}{l}\text { 40-49 hours } \\
(n=283)\end{array}$ & $\begin{array}{l}\text { More than } 50 \\
\text { hours }(n=94)\end{array}$ & $\mathbf{p}$ \\
\hline Individual features & \multicolumn{3}{|c|}{ Median (min:max) Mean \pm SD } & - \\
\hline 1. Overall perceptions of patient safety & $\begin{array}{l}75(0: 100) \\
70.23 \pm 30.67\end{array}$ & $\begin{array}{l}75(0: 100) \\
65.81 \pm 31.14\end{array}$ & $\begin{array}{l}50(0: 100) \\
56.91 \pm 31.56\end{array}$ & $0.012^{*}$ \\
\hline 2. Frequency of events reported & $\begin{array}{l}33.3(0: 100) \\
43.65 \pm 42.97\end{array}$ & $\begin{array}{l}33.3(0: 100) \\
44.28 \pm 44.22\end{array}$ & $\begin{array}{l}0(0: 100) \\
35.81 \pm 42.4\end{array}$ & 0.274 \\
\hline 3. Teamwork across units & $\begin{array}{l}50(0: 100) \\
55.65 \pm 36.68\end{array}$ & $\begin{array}{l}50(0: 100) \\
46.37 \pm 34.88\end{array}$ & $\begin{array}{l}50(0: 100) \\
48.4 \pm 34.54\end{array}$ & 0.112 \\
\hline 4. Handoffs and transitions & $\begin{array}{l}75(0: 100) \\
59.52 \pm 34.47\end{array}$ & $\begin{array}{l}50(0: 100) \\
54.77 \pm 34.19 \\
\end{array}$ & $\begin{array}{l}50(0: 100) \\
52.65 \pm 34.48 \\
\end{array}$ & 0.374 \\
\hline 5. Supervisor/manager expectations and actions promoting patient safety & $\begin{array}{l}75(0: 100) \\
59.22 \pm 36.56\end{array}$ & $\begin{array}{l}50(0: 100) \\
47.52 \pm 34.18\end{array}$ & $\begin{array}{l}50(0: 100) \\
41.22 \pm 33.54\end{array}$ & $0.002^{*}$ \\
\hline 6. Organizational learning - continuous improvement & $\begin{array}{l}66.7(0: 100) \\
61.11 \pm 32.66\end{array}$ & $\begin{array}{l}66.7(0: 100) \\
56.65 \pm 35.48\end{array}$ & $\begin{array}{l}66.7(0: 100) \\
49.65 \pm 36.83\end{array}$ & 0.111 \\
\hline 7. Teamwork within units & $\begin{array}{l}100(0: 100) \\
78.27 \pm 31.94\end{array}$ & $\begin{array}{l}75(0: 100) \\
71.2 \pm 33.17\end{array}$ & $\begin{array}{l}75(0: 100) \\
72.87 \pm 32.92\end{array}$ & 0.139 \\
\hline 8. Communication openness & \begin{tabular}{|l|}
$66.7(0: 100)$ \\
$55.95 \pm 36.65$ \\
\end{tabular} & $\begin{array}{l}66.7(0: 100) \\
53.94 \pm 32.31 \\
\end{array}$ & $\begin{array}{l}33.3(0: 100) \\
41.13 \pm 34.72\end{array}$ & $0.004^{*}$ \\
\hline 9. Feedback and communication about error & $\begin{array}{l}66.7(0: 100) \\
67.85 \pm 32.91\end{array}$ & $\begin{array}{l}66.7(0: 100) \\
62.77 \pm 35.8\end{array}$ & $\begin{array}{l}66.7(0: 100) \\
53.9 \pm 38.21\end{array}$ & $0.040^{*}$ \\
\hline 10. Non-punitive response to error & $\begin{array}{l}33.3(0: 100) \\
39.67 \pm 33.33\end{array}$ & $\begin{array}{l}33.3(0: 100) \\
29.91 \pm 33.34\end{array}$ & $\begin{array}{l}0(0: 100) \\
18.08 \pm 26.62\end{array}$ & $0.000^{\prime}$ \\
\hline 11. Staffing & $\begin{array}{l}50(0: 75) \\
38.69 \pm 19.56\end{array}$ & $\begin{array}{l}20(0: 100) \\
32.07 \pm 20.49\end{array}$ & $\begin{array}{l}25(0: 75) \\
25.26 \pm 20.89\end{array}$ & $0.000^{\prime}$ \\
\hline 12. Hospital management support for patient safety & $\begin{array}{l}66.7(0: 100) \\
58.73 \pm 39.95\end{array}$ & $\begin{array}{l}66.7(0: 100) \\
49.47 \pm 38.63\end{array}$ & $\begin{array}{l}33.3(0: 100) \\
39.53 \pm 39.11\end{array}$ & $0.005^{*}$ \\
\hline
\end{tabular}


and "hospital management support for patient safety" were determined differently among to participant.

\section{Discussion}

In this study, the perception of patient safety culture of health workers working in pediatric services and some factors affecting them were examined. When the percentage of positive answers by the health workers given in the "HSoPSC" items and the percentages of sub-dimensions were examined, the scale overall score was determined to be $51.0 \%$ according to the findings obtained. As a result of this research, the percentage of patient safety culture perceptions of healthcare professionals working in pediatric wards was evaluated as medium level. Studies with a higher percentage of this percentage have been reached in the literature. Chen and Li (14) reported $64 \%$ of their work in Taiwan, Sorra et al. (15) stated that employees' perception of patient safety culture was $75 \%$.
Health workers' responses to the "HSoPSC" were found to have the highest positive response rate of $71.55 \%$ in the "teamwork across units" sub-dimension in this study. This result is similar to some studies conducted before (16-19). In one study conducted in Taiwan, teamwork was reported to be $78 \%$ and teamwork among the units was reported to be $57 \%$ (13). In the study of Pronovost et al. (20), nurse managers (90\%), physicians (76\%) and nurses (71\%) reported positive relationships with their teammates. In another study, nurses reported that they were not worried about teamwork in their departments, but were worried about working with other units and that the cooperation between them was not good (21). According to these results, it can be said that health workers attach importance to teamwork in units, but still need to be supported. Teamwork is an important element in providing quality patient care and improving patient safety. Common values,

Table IV. Employees' views on sub-dimensions of patient safety culture in their institutions

\begin{tabular}{|c|c|c|c|c|c|}
\hline \multirow{3}{*}{$\begin{array}{l}\text { Hospital survey on patient safety culture sub-dimensions } \\
\text { Individual features }\end{array}$} & \multicolumn{5}{|c|}{ Patient safety in the institution } \\
\hline & \multicolumn{2}{|c|}{ There is not } & \multicolumn{3}{|c|}{ There is } \\
\hline & $n$ & $\begin{array}{l}\text { Median } \\
\text { (min:max) } \\
\text { Mean } \pm \text { SD }\end{array}$ & $\mathbf{n}$ & $\begin{array}{l}\text { Median } \\
\text { (min:max) } \\
\text { Mean } \pm \text { SD }\end{array}$ & $\mathbf{p}$ \\
\hline 1. Overall perceptions of patient safety & 30 & $\begin{array}{l}50(0: 100) \\
53.33 \pm 31.98\end{array}$ & 98 & $\begin{array}{l}75(0: 100) \\
72.28 \pm 28.16\end{array}$ & $0.004^{*}$ \\
\hline 2. Frequency of events reported & 30 & $\begin{array}{l}0(0: 100) \\
37.78 \pm 45.26\end{array}$ & 96 & $\begin{array}{l}33.33(0: 100) \\
46,18 \pm 43,63\end{array}$ & 0.322 \\
\hline 3. Teamwork across units & 30 & $\begin{array}{l}25(0: 100) \\
34.17 \pm 33.79 \\
\end{array}$ & 97 & $\begin{array}{l}75(0: 100) \\
65.21 \pm 34.42\end{array}$ & $0.001^{*}$ \\
\hline 4. Handoffs and transitions & 30 & $\begin{array}{l}50(0: 100) \\
45.83 \pm 33.53\end{array}$ & 97 & $\begin{array}{l}75(0: 100) \\
72.68 \pm 28.66\end{array}$ & $0.001^{*}$ \\
\hline $\begin{array}{l}\text { 5. Supervisor/manager expectations and actions promoting patient } \\
\text { safety }\end{array}$ & 29 & $\begin{array}{l}50(0: 100) \\
47.41 \pm 35.57\end{array}$ & 96 & $\begin{array}{l}50(0: 100) \\
49.48 \pm 34.98\end{array}$ & $0.783^{*}$ \\
\hline 6. Organizational learning - continuous Improvement & 30 & $\begin{array}{l}33.33(0: 100) \\
45.56 \pm 34.45\end{array}$ & 98 & $\begin{array}{l}66.67(0: 100) \\
65.82 \pm 35.20\end{array}$ & $0.006^{*}$ \\
\hline 7. Teamwork within units & 30 & $\begin{array}{l}75(0: 100) \\
69.17 \pm 35.16 \\
\end{array}$ & 98 & $\begin{array}{l}100(0: 100) \\
83.50 \pm 25.44\end{array}$ & $0.032^{*}$ \\
\hline 8. Communication openness & 30 & $\begin{array}{l}66.67(0: 100) \\
47.78 \pm 33.54 \\
\end{array}$ & 97 & $\begin{array}{l}66.67(0: 100) \\
63.23 \pm 34.52 \\
\end{array}$ & $0.030^{*}$ \\
\hline 9. Feedback and communication about error & 30 & $\begin{array}{l}66.67(0: 100) \\
56.67 \pm 32.93 \\
\end{array}$ & 97 & $\begin{array}{l}100(0: 100) \\
70.79 \pm 35.44\end{array}$ & $0.027^{*}$ \\
\hline 10. Non-punitive response to error & 30 & $\begin{array}{l}0(0: 100) \\
18.89 \pm 27.24\end{array}$ & 98 & $\begin{array}{l}33.33(0: 100) \\
32.14 \pm 32.48 \\
\end{array}$ & $0.035^{*}$ \\
\hline 11. Staffing & 30 & $\begin{array}{l}25(0: 50) \\
21.67 \pm 17.04\end{array}$ & 98 & $\begin{array}{l}25(0: 75) \\
32.40 \pm 19.18\end{array}$ & $0.006^{*}$ \\
\hline 12. Hospital management support for patient safety & 30 & $\begin{array}{l}0(0: 100) \\
31.11 \pm 37.07\end{array}$ & 97 & $\begin{array}{l}66.67(0: 100) \\
63.75 \pm 37.19\end{array}$ & $0.001^{*}$ \\
\hline
\end{tabular}


attitudes and beliefs at the highest level of the institution should be at the same level in all units in order to create an effective safety culture. In addition, in order to create an effective safety culture, employees should be able to communicate frequently and confidently with those outside their own units.

The lowest positive response percentage of pediatric workers participating in this study was found to be "nonpunitive response to error" at $28.06 \%$. The non-punitive response dimension to error appears to be generally inadequate. A low score from this sub-dimension may result from employees thinking that they can meet with more punitive responses to the mistakes made.With respect to other studies, Sorra et al. (15), Chen and Li (14) and Sorra et al. (22) found that employees' non-punitive response to error were $37 \%, 44 \%$ and $45 \%$, respectively. Research conducted by Scherer and Fitzpatrick (23) found that $63.0 \%$ of physicians and nurses expressed anxiety about being penalized when they made mistakes. This rate is lower in studies conducted in the United States, China and Saudi Arabia (17-19), but were found to be higher in a study in Norway (16). These results show that a response approach which is not punitive to an error varies according to the institution, and is not generally adequate. It can contribute to taking certain measures by improving the nonpunitive missions of hospitals for healthcare workers, and encouraging the improvement of error reporting.

It was determined that the average scores of positive responses in the "communication openness", "feedback and communication about error" and "handoffs and transitions" subscales of single health-care workers were higher than married health-care workers. The married health-care workers were found to have higher mean scores in the "staffing" sub-dimension. It can be said that single health workers working in pediatric services find communication and exchange especially valuable. Single employees are considered to have this point of view because they are younger. Married employees are thought to have been assessed because of their concerns about taking time from their marriage. Abdou and Saber (24) worked with nurses to perceive a patient safety culture. As a result of the study, they reached that marital status was not effective in the sub-dimensions of the security culture scale used.

In the research findings, it is thought that the sufficient employment of qualified health personnel is not provided considering that the health workers we have identified are working 40-49 hours per week or more than 50 hours. In the health-care services, nurses constitute the largest group in proportion to other health workers. A lack of nurses, especially the absence of well-trained and experienced nurses, leads to an increase in undesirable incidents. In terms of patient care, a lack of staff, individuals who do not work with equal sacrifice, and excessive work-loads are among the reasons for showing less positive scores. In a joint study in China, Taiwan and the United States, the effect of nurse working hours on patient safety culture was investigated. In all three countries, there was a correlation between the decrease in the degree of patient safety culture and the increase in the number of reported incidents (25). Rogers et al. (26) showed in their study that the rate of error increased among nurses working more than 12 hours a day and more than 40 hours a week. Since the education and training process of health care personnel requires more time and economic costs, and the number of employees assigned to this task is not sufficient to meet its needs, it is thought that the current health care workers have to continue their working lives while working overtime hours.

Nordin (27) studied patient safety with healthcare professionals with 10 years or more work experience. As a result, they stated that the working hour was effective in the "overall perception of patient safety" sub-dimension similar to our study. However, there is no similarity in the average positive response percentage of "frequency of reported events", "staffing", "hospital management support for patient safety" and "teamwork across units" sub-dimensions between our study and Nordin's study (27). Unlike our study, Abdou and Saber (24) did not find a statistically significant difference between working time and safety culture in the study of perception of the patient's safety culture. The sensitivity of experienced healthcare professionals who have been in the hospital work for a long time should be considered by hospital management. Alharbi et al. (28) stated that the patient's safety culture was higher among pharmacists than nurses.

The average of the positive responses of the employees in the pediatric service and pediatric intensive care units from the "organizational learning - continuous improvement" and "hospital management support for patient safety" subdimensions are low. It is thought that employees in both units have more work load, so there is not enough time for continuous improvement. In addition, it is thought that employees in these units face more cases of patient safety, and especially more often need to receive support from management. For these reasons, we can say that there is no support structure in the institutions in the development of patient safety culture in the hospital. 
Aiken et al. (29) found that low level patient safety in the units in which nurses work affects their job satisfaction and their considerations to quit. Some studies in other countries have shown that this rate varies between 26.3 and $72 \%$ (1619). In a study involving different health professional groups, for the majority of nurses in five hospitals in Belgium, the participants stated that executive support was very inadequate.

\section{Study Limitations}

In contrast, in another study, employees found the support of the management to be quite adequate in terms of patient safety (23). It is expected that an institution's patient safety culture will not differ according to the departments studied. It is hoped that the safety culture, which includes factors such as giving importance to patient safety, evaluating patient safety, providing financial resources, evaluating risks and reporting, does not differ from one institution or even from department to department, and should be fulfilled in every department.

\section{Conclusion}

Theseresultsshow thatpediatrichealthcareprofessionals who work in patient safety culture at the desired level of perception adopt a positive line of professional conduct in health care. This study also demonstrates that this type of professional conduct could permeate to the whole group in which they serve, and the following recommendations can be made to that end:

- to develop processes that facilitate the planning, reporting, analysis and learning of the problems of patient safety in hospitals,

- to provide staff-specific training with a view to create an adequate number of experienced and competent employees,

- to increase the encouragement and support for staff in patient safety issues faced by the administrators,

- for managers to take into consideration patient safety regulations in favour of health workers, attaching special importance to working hours.

\section{Ethics}

Ethics Committee Approval: The approval of Uludağ University Faculty of Medicine Clinical Research Ethics Committee (52588837-000/421) concerning the subject, purpose and method of the research were obtained, and the study was launched upon obtaining permission for clinical practice from the hospitals included in the research.
Informed Consent: Individual permission from the participants was acquired via an informed consent form during the study.

Peer-review: Externally peer-reviewed.

\section{Authorship Contributions}

Surgical and Medical Practices: Y.K., G.M., Concept: Y.K., G.M., Design: Y.K., G.M., Data Collection or Processing: Y.K., G.M., Analysis or Interpretation: Y.K., G.M., Literature Search: Y.K., G.M., Writing: Y.K., G.M.

Conflict of Interest: None of the authors had conflict of interest.

Financial Disclosure: The authors declared that this study received no financial support.

\section{References}

1. Kumar B. Patient safety and quality metrics in pediatric hospital medicine. Pediatr Clin North Am 2016; 63:283-91.

2. Berman L, Rangel S, Goldin A, et al. Safety culture among pediatric surgeons: a national survey of attitudes and perceptions of patient safety. J Pediatr Surg 2018; 53:381-95.

3. Singer S, Lin S, Falwell A, Gaba D, Baker L. Relationship of safety climate and safety performance in hospitals. Health Serv Res 2009; 44:399-421.

4. Kohn LT, Corrigan J, Donaldson MS. To err is human: building a safer health system. Institute of Medicine (US) Committee on Quality of Health Care in America [Internet] 2000, 2019.

5. Hellings J, Schrooten W, Klazinga N, Vleugels A. Challenging patient safety culture: survey results. Int I Health Care Qual Assur 2007; 20:620-32.

6. Mi Cho S, Choi J. Patient safety culture associated with patient safety competencies among registered nurses. I Nurs Scholarsh 2018; 50:549-57.

7. Lacey S, Smith JB, Cox K. Pediatric safety and quality. In R. Hughes (Ed.), Patient safety and quality: An evidence-based handbook for nurses. Rockville MD: Agency for Healthcare; 2008; 411-40.

8. Valentini RP. Patient safety and quality improvement: what the pediatric trainee needs to know. Prog Pediatr Cardiol 2017; 44:47-53.

9. Abu-El-Noor NI, Hamdan MA, Abu-El-Noor MK, Radwan AKS, Alshaer AA. Safety culture in neonatal intensive care units in the Gaza Strip, Palestine: A need for policy change. I Pediatr Nurs 2017; 33:76-82.

10. Haerkens M, Jenkins DH, Van der Hoeven JG. Crew resource management in the ICU: the need for culture change. Ann Intesive Care 2012; 2:39.

11. Özkan A. Adaptation of patient safety measures to perinatal clinics and implementation guidelines. Doctoral thesis. Istanbul: Marmara University, Health Science Institues; 2012.

12. Nieva VF, Sorra J. Safety culture assessment: a tool for improving patient safety in health care organizations. Qual Saf Health Care 2003; 12:17-23. 
13. Bodur S, Filiz E. A survey on patient safety culture in primary healthcare services in Turkey. Int I Qual Health Care 2009; 21:348-55

14. Chen C, Li H. Measuring patient safety culture in taiwan using the hospital survey on patient safety culture (HSOPSC). BMC Health Serv Res 2010; 10:152.

15. Sorra J, Famolaro T, Dyer N, Nelson D, Khanna K. Patient Safety. Hospital Survey on patient safety culture: 2008 comparative database report. United States: AHRQ Publication 2008.

16. Balas MC, Scott LD, Rogers AE. The Prevalence and nature of errors and near errors reported by hospital staff nurses. Appl Nurs Res 2004; 17:224-30.

17. Elliott $M$, Liu Y. The nine rights of medication administration: an overview. Br J Nurs 2010; 19:300-5.

18. Snyder SR, Favoretto AM, Derzon $J \mathrm{H}$, et al. Effectiveness of barcoding for reducing patient specimen and laboratory testing identification errors: a laboratory medicine best practices systematic review and meta- analysis. Clin Biochem 2012; 45:988-98.

19. Wakefield A, Attree M, Braidman I, Carlisle C, Johnson M, Cooke $\mathrm{H}$. Patient Safety: Do Nursing and Medical Curricula Address This Theme? Nurse Educ Today 2005; 25:333-40.

20. Pronovost P), Weast B, Holzmueller CG, et al. Evaluation of the culture of safety: survey of clinicians and managers in an academic medical center. Qual Saf Health Care 2003; 12:405-10.

21. Kim J, An K, Kim MK, Yoon SH. Nurses' perception of error reporting and patient safety culturein Korea, I Nurs Res 2007; 29:827.
22. Wagner C, Smits M, Sorra J, Huang CC. Assessing Patient Safety Culture in Hospitals Across Countries. Int I Qual Health Care 2013; 25:213-21.

23. Scherer D, Fitzpatrick J. Perceptions of Patient Safety Culture Among Physicians and RNs in the Perioperative Area. AORN Journal 2008; 87:163-75.

24. Abdou HA, Saber KM. A Baseline assessment of patient safety culture among nurses at student university hospital. World Journal of Medical Sciences 2011; 6:17-26.

25. Wu Y, Fujita S, Seto K, et al. The impact of nurse working hours on patient safety culture: a cross-national survey including Japan, the United States and Chinese Taiwan using the Hospital Survey on Patient Safety Culture. BMC Health Serv Res 2013; 13:394.

26. Rogers AE, Hwang WT, Scott LD. The working hours of hospital staff nurses and patient safety. Health Aff 2004; 23:202-12.

27. Nordin A. Patient safety culture in hospital settingsmeasurements, health care staff perceptions and suggestions for Improvement. Karlstad University Studies. Doctoral thesis [Internet] 2015, 2019

28. Alharbi W, Cleland J, Morrison Z. Assesment of patient safety culture in an adult oncology department in Saudi Arabia. Oman Med I 2018; 33:200-8.

29. Aiken LH, Sermeus W, Sloane MD. Patient safety, satisfaction, and quality of hospital care: cross sectional surveys of nurses and patients in 12 countries in europe and the United States. BMJ 2012; 344:1717. 